\title{
Risk factors for worsening to diabetes in subjects with impaired glucose tolerance
}

\author{
T.Kadowaki ${ }^{1,2}$, Y.Miyake ${ }^{1}$, R. Hagura ${ }^{1}$, Y.Akanuma ${ }^{2}$, H. Kajinuma ${ }^{1}$, N. Kuzuya ${ }^{1}$, F. Takaku² and K. Kosaka ${ }^{3}$ \\ ${ }^{1}$ Institute for Adult Diseases, Asahi Life Foundation, ${ }^{2}$ Third Department of Internal Medicine, Faculty of Medicine, University of Tokyo, and \\ ${ }^{3}$ Toranomon Hospital, Tokyo, Japan
}

\begin{abstract}
Summary. In a 5-12 year follow-up study of 288 subjects with impaired glucose tolerance after a $100-\mathrm{g}$ glucose load, 48 worsened to overt Type 2 (non-insulin-dependent) diabetes with the elevation of fasting blood glucose. The initial level of blood glucose was a major predictor of subsequent worsening to diabetes. In addition, subjects with a lower insulin response to glucose showed a higher incidence of worsening to the disease, irrespective of blood glucose levels. Multivariate analysis indicated that a diminished insulin response and a high
\end{abstract}

maximal body weight index, as well as a high level of fasting and 2-h glucose values at the initial 100-g oral glucose tolerance test were significant independent risk factors for the development of diabetes in Japanese subjects.

Key words: Impaired glucose tolerance, Type 2 diabetes, worsening to diabetes, multivariate analysis, diminished insulin response, obesity.
A prospective follow-up study of subjects with impaired glucose tolerance is a useful way to study the aetiology and pathogenesis of diabetes mellitus. There have been several follow-up studies of subjects with impaired glucose tolerance reported in the literature [1-8]. These studies agree that the initial degree of hyperglycaemia is an important index predictive of subsequent worsening to diabetes, but the roles of obesity and low insulin response as predictive factors remain controversial.

Recently, based on the Second Report of the WHO Expert Committee on Diabetes Mellitus [9], the Japan Diabetic Society proposed a new set of diagnostic criteria for oral glucose tolerance tests [10]. In this proposal, a 'borderline type' was established between normality and diabetes. This prompted us to define a high risk group for worsening to diabetes in the 'borderline type'.

It is the purpose of the present study to report the results of a 5-12 year follow-up of 288 subjects of the 'borderline type' and to elucidate the risk factors for worsening to diabetes with special reference to diminished insulin response and obesity.

\section{Subjects and methods}

\section{Subjects}

The subjects were selected from the out-patient clinic of the Institute for Adult Diseases, Asahi Life Foundation, whose first visit was between 1 January 1969 and 31 December 1976. A total of 288 subjects was observed for $5-12$ years $(8.7 \pm 2.6$ years, mean $\pm S D)$. They pre-
Sented with intermediate glucose levels at the initial 100-g oral glucose tolerance test corresponding with the 'borderline type' of the Japan Diabetic Society, as defined below.

Blood glucose was determined by a glucose oxidase method using a glucose-autoanalyser (Hitachi, Tokyo, Japan) from capillary whole blood. Samples were taken before and 30, 60,120 and $180 \mathrm{~min}$ after a $100-\mathrm{g}$ glucose load. Plasma immunoreactive insulin (IRI) was measured by a double-antibody technique [11] in venous blood samples withdrawn at the same time, the intra-assay variance being $8.1 \%$ and the interassay variance $11.4 \%$. The glucose tolerance test results were divided as follows: (a) diabetic type: fasting blood glucose $\geqslant$ $6.7 \mathrm{mmol} / 1(120 \mathrm{mg} / 100 \mathrm{ml})$ and $/$ or $2-\mathrm{h}$ blood glucose $\geqslant 13.3 \mathrm{mmol} / 1$ (240 mg/100 ml); (b) 'borderline type': fasting blood glucose between $5.6-6.7 \mathrm{mmol} / 1(100-120 \mathrm{mg} / 100 \mathrm{ml})$, and /or 1-h blood glucose $\geqslant$ $8.9 \mathrm{mmol} / 1(160 \mathrm{mg} / 100 \mathrm{ml})$, and $/$ or 2 -h blood glucose between $7.2-13.3 \mathrm{mmol} / 1(130-240 \mathrm{mg} / 100 \mathrm{ml})$; (c) normal type: fasting blood glucose $<5.6 \mathrm{mmol} / 1(100 \mathrm{mg} / 100 \mathrm{ml})$, and 1 -h blood glucose < $8.9 \mathrm{mmol} / 1(160 \mathrm{mg} / 100 \mathrm{ml})$, and 2 -h blood glucose $<7.2 \mathrm{mmol} / 1$ $(130 \mathrm{mg} / 100 \mathrm{ml})$.

According to the comparison of $75 \mathrm{~g}$ and $100 \mathrm{~g}$ oral glucose tolerance tests made by Hagura [12], 2-h blood glucose values of $7.2-13.3 \mathrm{mmol} / 1(130-240 \mathrm{mg} / 100 \mathrm{ml})$ after a $100 \mathrm{-g}$ glucose load correspond with values of $6.7-11.1 \mathrm{mmol} / 1(120-200 \mathrm{mg} / 100 \mathrm{ml})$ after a 75-g glucose load. Therefore, the range of blood glucose values of the 'borderline type', as defined by the Japan Diabetic Society, has a similar upper limit to 'impaired glucose tolerance' in the diagnostic criteria of the WHO Expert Committee on Diabetes Mellitus [9], but a lower limit that is $1.1 \mathrm{mmol} / 1(20 \mathrm{mg} / 100 \mathrm{ml})$ lower.

Subjects previously known to be hyperglycaemic or who were receiving treatment were excluded.

\section{Baseline variables}

At the initial examination, the following nine baseline variables were recorded whose relationships to the deterioration of glucose tolerance were investigated: (a) age; (b) sex; (c) family history (judged as posi- 
tive when either parents, siblings or children had diabetes); (d) past maximal body weight index $(\%)=$ [past maximal body weight $(\mathrm{kg}) /$ (body height $(\mathrm{cm})-100) \times 0.9(\mathrm{~kg})] \times 100$ [13] (when a subject had a highest body weight index before the initial visit, this value was used and when the highest body weight index was recorded at the initial visit, this value was used); (e) body weight index at the first visit; (f) fasting blood glucose at the initial 100 -g oral glucose tolerance test; (g) 2-h blood glucose at the initial 100-g oral glucose tolerance test; (h) increments of insulin $30 \mathrm{~min}$ after a $100 \mathrm{~g}$ glucose load above the fasting values at the initial examination $\left(\triangle \mathrm{IRI}_{(30)}\right)$; (i) the ratio of increments of insulin to that of blood glucose $30 \mathrm{~min}$ after a $100 \mathrm{~g} \mathrm{glu}-$ cose load at the initial examination $\left(\triangle \mathrm{IRI} / \Delta \mathrm{BG}_{(30)}\right)$. First, since the absolute rise in blood insulin depends upon the glycaemic stimulus, it is necessary to estimate insulin response taking blood glucose rise into consideration $[14,15]$. Second, impairment of 'early-phase' insulin response to glucose is characteristic of diabetic metabolism $[14,16]$. In these respects, the ratio of increment of insulin to that of blood glucose at $30 \mathrm{~min}$ after a $100 \mathrm{~g}$ glucose load provides a simple measure of $B$ cell function and this parameter has been regarded as one of the clinically useful indicies of insulin response [14, 17-19]. The value of $9.0 \mathrm{mU} / \mathrm{mmol}$ or $0.05 \mathrm{mU} / \mathrm{mg}$ for $\triangle I R I / \triangle B_{(30)}$ serves as a meaningful point for insulin response based on the following observations: the majority of $\triangle \mathrm{IRI} / \triangle \mathrm{BG}_{(30)}$ values in healthy subjects are higher than $9.0 \mathrm{mU} / \mathrm{mmol}$ or $0.05 \mathrm{mU} / \mathrm{mg}$, while $\Delta \mathrm{IRI} / \Delta \mathrm{BG}_{(30)}$ values are almost invariably lower than $9.0 \mathrm{mU} / \mathrm{mmol}$ or $0.05 \mathrm{mU} / \mathrm{mg}$ in subjects with definite diabetes who had presented with a fasting blood glucose $\geqslant$ $7.8 \mathrm{mmol} / 1(140 \mathrm{mg} / 100 \mathrm{ml})[17,19]$. Thus, in the present report we define a low insulin response as $\Delta \mathrm{IRI} / \triangle B \mathrm{G}_{(30)}<9.0 \mathrm{mU} / \mathrm{mmol}$ or $0.05 \mathrm{mU} / \mathrm{mg}$ and a normal-high insulin response as $\Delta I R I / \Delta B G_{(30)} \geqslant$ $9.0 \mathrm{mU} / \mathrm{mmol}$ or $0.05 \mathrm{mU} / \mathrm{mg}$.

\section{Worsening to overt diabetes}

After the initial visit, the patients were reviewed at $1-4$ month intervals for 5-12 years. Baseline variables were examined repeatedly at predetermined intervals; fasting blood glucose was examined approximately 4 monthly and ophthalmoscopy was performed yearly. They received no medication for diabetes during the observation period and were treated by diet alone; total calorie intake was restricted to $30 \mathrm{kcal} \cdot \mathrm{day}^{-1} \cdot \mathrm{kg}^{-1}$ ideal body weight.

Subjects were diagnosed as having definite or unequivocal diabetes when they fulfilled at least one of the following criteria: (1) fasting blood glucose $\geqslant 7.8 \mathrm{mmol} / 1$ ( $140 \mathrm{mg} / 100 \mathrm{ml}$ ) (capillary whole blood); (2) development of clear diabetic retinopathy; scattered microaneurysms plus fasting blood glucose $\geqslant 6.7 \mathrm{mmol} / 1(120 \mathrm{mg} / 100 \mathrm{ml})$.

\section{Statistical analysis}

Proportional hazard function analysis [20], which takes varying follow-up times into account, was used to determine the roles of variables at the first examination in relation to worsening to diabetes. Coefficients were calculated from the linear discriminant function of the variables. Selection of variables was done in a stepwise fashion by use of a backward selection method. In practice, the variable with the lowest $t$-value was discarded one by one until each $t$-value of the variables reached the level of over $\sqrt{2}$.

\section{Results}

\section{Baseline characteristics}

After follow-up for 5-12 years, 48 of the 288 subjects developed frank diabetes. Among these 48 subjects, 34 had a fasting blood glucose $\geqslant 7.8 \mathrm{mmol} / 1$ ( $140 \mathrm{mg} /$ $100 \mathrm{ml}$ ) without retinopathy, seven subjects had clear diabetic retinopathy and the remaining seven had both
Table 1. Blood glucose, plasma immunoreactive insulin and IRI : BG ratio in incremental changes above the fasting values $(\triangle I R I / \triangle B G)$ at the initial 100 -g oral glucose tolerance test

\begin{tabular}{|c|c|c|c|}
\hline & & $\begin{array}{l}\text { Worsening to } \\
\text { diabetes } \\
(n=48)\end{array}$ & $\begin{array}{l}\text { Not wor- } \\
\text { sening to } \\
\text { diabetes } \\
(n=240)\end{array}$ \\
\hline Blood glucose $(\mathrm{mmol} / \mathrm{l})$ & $\begin{array}{l}\text { basal } \\
30 \mathrm{~min} \\
60 \mathrm{~min} \\
120 \mathrm{~min} \\
180 \mathrm{~min}\end{array}$ & $\begin{array}{r}5.7 \pm 0.7^{\mathrm{d}} \\
10.6 \pm 1.2^{\mathrm{c}} \\
13.0 \pm 1.8^{\mathrm{d}} \\
10.6 \pm 1.1^{\mathrm{d}} \\
7.2 \pm 2.0^{\mathrm{c}}\end{array}$ & $\begin{array}{r}5.2 \pm 0.6 \\
10.0 \pm 1.8 \\
10.9 \pm 2.3 \\
8.7 \pm 1.9 \\
6.4 \pm 1.6\end{array}$ \\
\hline $\begin{array}{l}\text { Plasma immunoreactive } \\
\text { insulin }(\mathrm{mU} / \mathrm{l})\end{array}$ & $\begin{array}{l}\text { basal } \\
30 \mathrm{~min} \\
60 \mathrm{~min} \\
120 \mathrm{~min}^{\mathrm{a}} \\
180 \mathrm{~min}^{\mathrm{b}}\end{array}$ & $\begin{array}{l}14.2 \pm 8.3 \\
37.8 \pm 22.9^{d} \\
69.8 \pm 46.8 \\
78.5 \pm 62.4 \\
43.2 \pm 29.8\end{array}$ & $\begin{array}{l}13.1 \pm 8.6 \\
53.9 \pm 30.9 \\
75.8 \pm 48.4 \\
70.2 \pm 57.5 \\
42.4 \pm 31.2\end{array}$ \\
\hline$\Delta \mathrm{IRI} / \Delta \mathrm{BG}(\mathrm{mU} / \mathrm{mmol})$ & $\begin{array}{l}\text { basal } \\
30 \mathrm{~min} \\
60 \mathrm{~min} \\
120 \mathrm{~min}^{\mathrm{a}} \\
180 \mathrm{~min}^{\mathrm{b}}\end{array}$ & $\begin{array}{l}- \\
4.9 \pm 4.3^{\mathrm{d}} \\
7.6 \pm 5.4^{\mathrm{c}} \\
13.1 \pm 9.2 \\
19.3 \pm 15.2\end{array}$ & $\begin{array}{r}- \\
8.5 \pm 6.6 \\
10.8 \pm 8.1 \\
16.6 \pm 11.7 \\
24.4 \pm 18.8\end{array}$ \\
\hline
\end{tabular}

Results expressed as mean \pm SD. ${ }^{a, b} n=32$ for those worsening to diabetes and $n=170$ for those not worsening to diabetes; ${ }^{c} p<0.05,{ }^{d} p<$ 0.01: for the difference between those worsening to diabetes and those not worsening to diabetes

Table 2. Baseline variables in relation to worsening to diabetes

\begin{tabular}{|c|c|c|}
\hline Variable & $\begin{array}{l}\text { Worsening } \\
\text { to diabetes } \\
(n=48)\end{array}$ & $\begin{array}{l}\text { Not } \\
\text { worsening } \\
\text { to diabetes } \\
(n=240)\end{array}$ \\
\hline Age (years) & $49 \pm 11$ & $49 \pm 10$ \\
\hline Number of women $(\%)$ & 17 & 28 \\
\hline Positive family history (\%) & 35 & 31 \\
\hline $\begin{array}{l}\text { Maximal body weight index } \\
(\%)\end{array}$ & $127 \pm 20^{c}$ & $118 \pm 16$ \\
\hline $\begin{array}{l}\text { Body weight index at the } \\
\text { first visit }(\%)\end{array}$ & $114 \pm 20^{c}$ & $107 \pm 15$ \\
\hline $\begin{array}{l}\text { Fasting blood glucose } \\
\qquad(\mathrm{mmol} / \mathrm{l})\end{array}$ & $5.7 \pm 0.7^{c}$ & $5.2 \pm 0.6$ \\
\hline 2-h blood glucose $(\mathrm{mmol} / \mathrm{l})$ & $10.6 \pm 1.1^{\mathrm{c}}$ & $8.7 \pm 1.9$ \\
\hline$\Delta \operatorname{IRI}_{(30)}{ }^{\mathrm{a}}(\mathrm{mU} / \mathrm{l})$ & $23.6 \pm 17.7^{c}$ & $40.8 \pm 30.5$ \\
\hline$\Delta \mathrm{IRI} / \triangle \mathrm{BG}_{(30)}{ }^{\mathrm{b}}(\mathrm{mU} / \mathrm{mmol})$ & $4.9 \pm 4.3^{c}$ & $8.5 \pm 6.6$ \\
\hline
\end{tabular}

Results expressed as mean $\pm \mathrm{SD}$. ${ }^{a}$ Increments of insulin $30 \mathrm{~min}$ after a $100-\mathrm{g}$ glucose load above the fasting values; ${ }^{b}$ the ratio of increments of insulin to that of blood glucose $30 \mathrm{~min}$ after a $100 \mathrm{~g}$ glucose load; ${ }^{c} p<0.01$

a fasting blood glucose $\geqslant 7.8 \mathrm{mmol} / 1(140 \mathrm{mg} / 100 \mathrm{ml})$ and retinopathy. There was no difference in follow-up periods between those worsening to diabetes and those who did not worsen $(8.4 \pm 2.7$ and $8.7 \pm 2.5$ years (mean \pm SD), respectively).

We have compared those worsening to diabetes $(n=48)$ and those who did not worsen to diabetes $(n=240)$ with respect to their blood glucose curves (BG), plasma IRI values and IRI:BG ratio in incremental changes above the fasting values $(\triangle \mathrm{IRI} / \triangle \mathrm{BG})$ (Table 1) and also the nine baseline variables (Table 2). 
Mean blood glucose values were higher in those worsening to diabetes. The incremental changes of blood glucose $30 \mathrm{~min}$ after a glucose load, however, were similar between the two groups. Plasma IRI after a glucose load was significantly lower both in the absolute value and in its incremental change above the fasting value in those worsening to diabetes at $30 \mathrm{~min}$, although it was similar at other time points. The $\Delta \mathrm{IRI} / \Delta \mathrm{BG}$ curve was lower in those worsening to diabetes; at $30 \mathrm{~min}$ this was almost entirely due to a lower $\Delta$ IRI value and at 60,120 and $180 \mathrm{~min}$ this was mainly due to higher $\triangle \mathrm{BG}$ values. Maximal body weight index and body weight index at the first visit were significantly greater in those worsening to diabetes. No significant differences were found between the two groups in mean age, sex or family history.

\section{Multivariate analysis}

Baseline variables were examined further by proportional hazard function analysis (Table 3 ). Because of a close correlation $(r=0.77, p<0.001)$ between $\Delta \mathrm{IRI}_{(30)}$ and $\triangle \mathrm{IRI} / \triangle \mathrm{BG}_{(30)}$, the roles of these two variables were assessed separately. Initially, the eight baseline variables except $\Delta \mathrm{IRI}_{(30)}$, were used and regression coefficients and t-values were calculated. Subsequently, variables, were discarded one by one in a backward stepwise fashion according to the lowest t-value. As a final result, four variables (maximal body weight index, fasting blood glucose, 2-h blood glucose and $\Delta \mathrm{IRI} /$ $\left.\Delta \mathrm{BG}_{(30)}\right)$ were selected which reached conventional statistical significance (Table 3, Analysis 1). These variables are strongly predictive of subsequent worsening to diabetes; maximal body weight index, fasting blood glucose and 2-h blood glucose are positively related to worsening to diabetes, while $\Delta \mathrm{IRI} / \Delta \mathrm{BG}_{(30)}$ are inversely related to worsening. On the other hand, body weight index at the first visit was not adopted as a significant independent contributor in the final result of multivariate analysis, though it was significant in the univariate analysis. Next, the proportional hazard function analysis using $\Delta \mathrm{IRI}_{(30)}$ instead of $\triangle \mathrm{IRI} / \triangle \mathrm{BG}_{(30)}$ was performed and this gave similar results (Table 3, Analysis 2).

\section{Blood glucose level in relation to worsening to diabetes}

Figure 1 shows the rate of worsening to diabetes in relation to fasting blood glucose and $2-h$ blood glucose. As fasting blood glucose and 2-h blood glucose values become higher, the rate of worsening clearly increases. Worsening to diabetes was not observed in those with 2-h blood glucose $<6.7 \mathrm{mmol} / 1(120 \mathrm{mg} / 100 \mathrm{ml})$ and occurred 5.4 times more frequently in those with an initial 2-h blood glucose $\geqslant 10.0 \mathrm{mmol} / 1(180 \mathrm{mg} / 100 \mathrm{ml})$ than in those with a $2-\mathrm{h}$ blood glucose between $6.7-10.0 \mathrm{mmol} / 1(120-180 \mathrm{mg} / 100 \mathrm{ml})$.
Table 3. Hazard function analysis relating worsening to diabetes

\begin{tabular}{|c|c|c|}
\hline Variable & Coefficient & t-value \\
\hline \multicolumn{3}{|l|}{ Analysis I } \\
\hline \multicolumn{3}{|l|}{ Initial step } \\
\hline Age (years) & -0.38 & 0.88 \\
\hline Sex & -0.01 & 0.77 \\
\hline Family history & -0.02 & 0.09 \\
\hline $\begin{array}{l}\text { Maximal body weight index } \\
(\%)\end{array}$ & 0.03 & $2.20^{\mathrm{c}}$ \\
\hline $\begin{array}{l}\text { Body weight index at the first } \\
\text { visit }(\%)\end{array}$ & -0.00 & 0.03 \\
\hline $\begin{array}{l}\text { Fasting blood glucose } \\
(\mathrm{mmol} / \mathrm{l})\end{array}$ & 0.97 & $3.45^{\mathrm{d}}$ \\
\hline 2-h blood glucose $(\mathrm{mmol} / \mathrm{l})$ & 0.11 & $2.49^{\mathrm{c}}$ \\
\hline$\Delta \mathrm{IRI} / \Delta \mathrm{BG}^{\mathrm{a}}{ }_{(30)}(\mathrm{mU} / \mathrm{mmol})$ & -0.07 & 1.85 \\
\hline \multicolumn{3}{|l|}{ Final step } \\
\hline $\begin{array}{l}\text { Maximal body weight index } \\
(\%)\end{array}$ & 0.03 & $3.81^{\mathrm{d}}$ \\
\hline $\begin{array}{l}\text { Fasting blood glucose } \\
(\mathrm{mmol} / \mathrm{l})\end{array}$ & 0.97 & $3.68^{\mathrm{d}}$ \\
\hline 2-h blood glucose $(\mathrm{mmol} / \mathrm{l})$ & 0.13 & $3.00^{\mathrm{d}}$ \\
\hline$\Delta \mathrm{IRI} / \triangle \mathrm{BG}^{\mathrm{a}}{ }_{(30)}(\mathrm{mU} / \mathrm{mmol})$ & -0.07 & $2.03^{\mathrm{c}}$ \\
\hline \multicolumn{3}{|l|}{ Analysis 2} \\
\hline \multicolumn{3}{|l|}{ Initial step } \\
\hline Age (years) & -0.35 & 0.81 \\
\hline Sex & -0.01 & 0.72 \\
\hline Family history & -0.02 & 0.10 \\
\hline $\begin{array}{l}\text { Maximal body weight index } \\
(\%)\end{array}$ & 0.03 & $3.80^{\mathrm{d}}$ \\
\hline $\begin{array}{l}\text { Body weight index at the first } \\
\text { visit }(\%)\end{array}$ & -0.00 & 0.03 \\
\hline $\begin{array}{l}\text { Fasting blood glucose } \\
(\mathrm{mmol} / \mathrm{l})\end{array}$ & 0.95 & $3.38^{\mathrm{d}}$ \\
\hline 2-h blood glucose $(\mathrm{mmol} / \mathrm{l})$ & 0.13 & $3.03^{\mathrm{d}}$ \\
\hline$\Delta \operatorname{IRI}_{(30)} \mathrm{b}(\mathrm{mU} / 1)$ & -0.24 & 1.95 \\
\hline \multicolumn{3}{|l|}{ Final step } \\
\hline $\begin{array}{l}\text { Maximal body weight index } \\
(\%)\end{array}$ & 0.03 & $3.74^{\mathrm{d}}$ \\
\hline $\begin{array}{l}\text { Fasting blood glucose } \\
(\mathrm{mmol} / \mathrm{l})\end{array}$ & 0.97 & $3.60^{\mathrm{d}}$ \\
\hline 2-h blood glucose $(\mathrm{mmol} / \mathrm{l})$ & 0.14 & $3.26^{\mathrm{d}}$ \\
\hline$\Delta \operatorname{IRI}_{(30)}{ }^{\mathrm{b}}(\mathrm{mU} / 1)$ & -0.24 & $2.01^{\mathrm{c}}$ \\
\hline
\end{tabular}

a The ratio of increments of insulin to that of blood glucose $30 \mathrm{~min}$ after a $100-\mathrm{g}$ glucose load at the initial examination; ${ }^{b}$ Increments of insulin $30 \mathrm{~min}$ after a $100-\mathrm{g}$ glucose load above the fasting values; ${ }^{\mathrm{c}} p<$ $0.05 ;{ }^{\mathrm{d}} p<0.01$
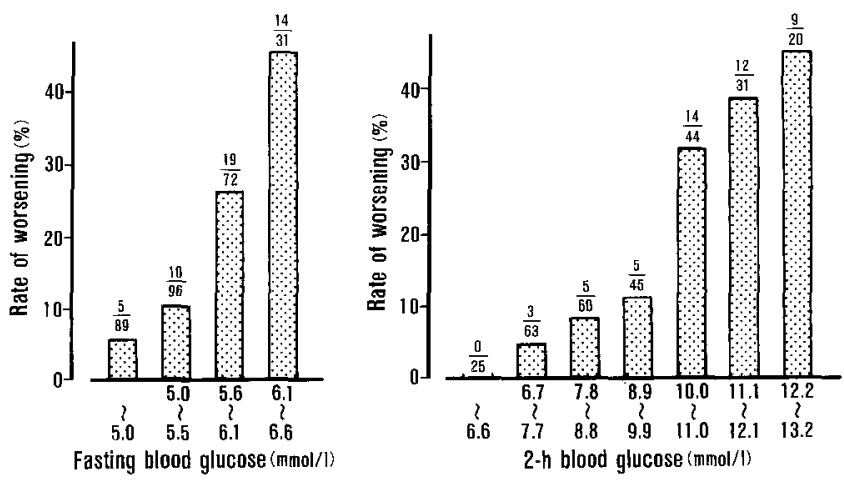

Fig. 1. Incidence of worsening to diabetes in relation to fasting and 2-h blood glucose after a 100 -g glucose load at the initial examination. Fractions shown above each column indicate the number of subjects with worsening (numerator) in the total subjects who belong to each class of blood glucose level (denominator) 
Table 4. Worsening to diabetes in relation to insulin response to glucose $\left(\triangle \mathrm{IRI} / \Delta \mathrm{BG}_{(30)}\right)$

\begin{tabular}{|c|c|c|c|c|c|c|}
\hline \multirow{2}{*}{$\begin{array}{l}\text { 2-h blood } \\
\text { glucose } \\
(\mathrm{mmol} / \mathrm{l})\end{array}$} & \multicolumn{6}{|c|}{ Insulin response to glucose: $\Delta I R I / \Delta \mathrm{BG}_{(30)}(\mathrm{mU} / \mathrm{mmol})$} \\
\hline & Number & Worsening $(\%)$ & Number & Worsening $(\%)$ & Number & $\begin{array}{l}\text { Worsening } \\
(\%)\end{array}$ \\
\hline$<6.7$ & 10 & $0(0)$ & 6 & $0(0)$ & 9 & $0(0)$ \\
\hline $6.7-10.0$ & 47 & $8(17)^{\mathrm{a}}$ & 62 & $4(7)$ & 59 & $1(2)$ \\
\hline
\end{tabular}

The values in parentheses denote the percentage of those worsening to diabetes; ${ }^{a} p<0.05$ versus normal or high group; ${ }^{b} p<0.01$ versus normal or high group

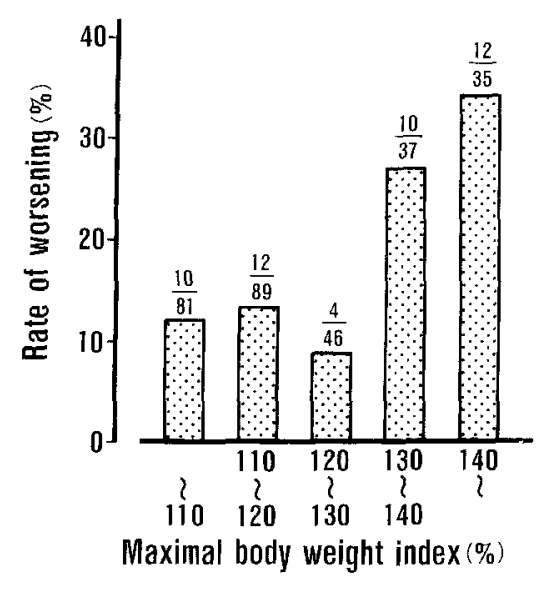

Fig. 2. Incidence of worsening to diabetes in relation to past maximal body weight index. Fractions shown on the top of each column indicate the number of worsening (numerator) in the total subjects who belong to each class of adiposity (denominator)

\section{Maximal obesity in relation to worsening to diabetes}

Figure 2 shows the rate of worsening to diabetes in relation to maximal body weight index. This figure indicates that severe obesity has a substantive impact on the subsequent development of diabetes. In fact, in 216 subjects with a maximal body weight index of $<130 \%$, only $26(12 \%)$ worsened to diabetes, while in 72 subjects with a maximal body weight index $\geqslant 130 \%$, as many as $22(31 \%)$ worsened to diabetes $(p<0.01)$. The influence of obesity was further assessed in the mild glucose intolerance group ( $2-\mathrm{h}$ blood glucose $<10.0 \mathrm{mmol} / 1$ or $180 \mathrm{mg} / 100 \mathrm{ml}$ ) and in the severe glucose intolerance group (2-h blood glucose $\geqslant 10.0 \mathrm{mmol} / 1$ or $180 \mathrm{mg}$ / $100 \mathrm{ml}$ ). In the mild glucose intolerance group, the rate of worsening to diabetes was not substantially different between the subjects with a maximal body weight index of $<130 \%$ and those with a maximal body weight index of $\geqslant 130 \%$; that is, $9.1 \%$ in the former and $8.1 \%$ in the latter. On the other hand, in the severe glucose intolerance group, worsening to diabetes occurred significantly more frequently in subjects with a maximal body weight index $\geqslant 130 \%$ than in those with a maximal body weight index of $<130 \%$ (49\% and $29 \%$, respectively; $p<0.01$ ).

\section{Insulin response in relation to worsening to diabetes}

Table 4 shows the rate of worsening to diabetes in relation to insulin response to glucose $\left(\Delta I R I / \triangle B G_{(30)}\right)$, taking blood glucose level (2-h blood glucose) into account. It is clearly demonstrated that subjects with lower values of $\triangle I R I / \triangle B G_{(30)}$ showed a higher incidence of worsening to diabetes, irrespective of $2-\mathrm{h}$ blood glucose levels.

In addition, because of the well-known effect of obesity on plasma IRI, subjects were classified into three groups according to their maximal body weight index; group 1 (maximal body weight index $<110 \%$, $n=81$ ), group 2 (maximal body weight index 110 $140 \%, n=172$ ), group 3 (maximal body weight index $\geqslant 140 \%, n=35$ ). Group 1 was regarded as a nonobese, group 2 as a mildly or moderately obese and group 3 as an extremely obese group. In each group, the values of $\Delta I R I / \triangle B G_{(30)}$ are shown in Figure 3 in relation to worsening to diabetes. For the sake of comparison, the values of $\Delta I R I / \triangle B G_{(30)}$ for 101 healthy subjects with normal glucose tolerance and 86 definite diabetics who had experienced fasting blood glucose $\geqslant 7.8 \mathrm{mmol} / 1$ $(140 \mathrm{mg} / 100 \mathrm{ml})$ are also plotted in this figure. In groups 1 and 2, deterioration to diabetes occurred almost exclusively in those with a low insulin response whose $\Delta \mathrm{IRI} / \Delta \mathrm{BG}_{(30)}$ values were below $4.5 \mathrm{mU} / \mathrm{mmol}$ and $9.0 \mathrm{mU} / \mathrm{mmol}$, respectively. On the other hand, in group 3 there was no such discriminating point of $\Delta I R I /$ $\triangle B G_{(30)}$ for the subsequent development of diabetes and a certain number of subjects with a normal or high insulin response $\left(\Delta \mathrm{IRI} / \Delta \mathrm{BG}_{(30)} ; 15.1-37.3 \mathrm{mU} / \mathrm{mmol}\right)$ did, in fact, develop diabetes. Moreover, as can be seen from Figure 3, in groups 1 and 2, the mean $\Delta I R I /$ $\triangle \mathrm{BG}_{(30)}$ values were significantly lower in those worsening to diabetes compared with those who did not worsen. However, in group 3, there was no substantial difference in mean $\triangle \mathrm{IRI} / \triangle \mathrm{BG}_{(30)}$ values between those who worsened and those who did not worsen to diabetes. 


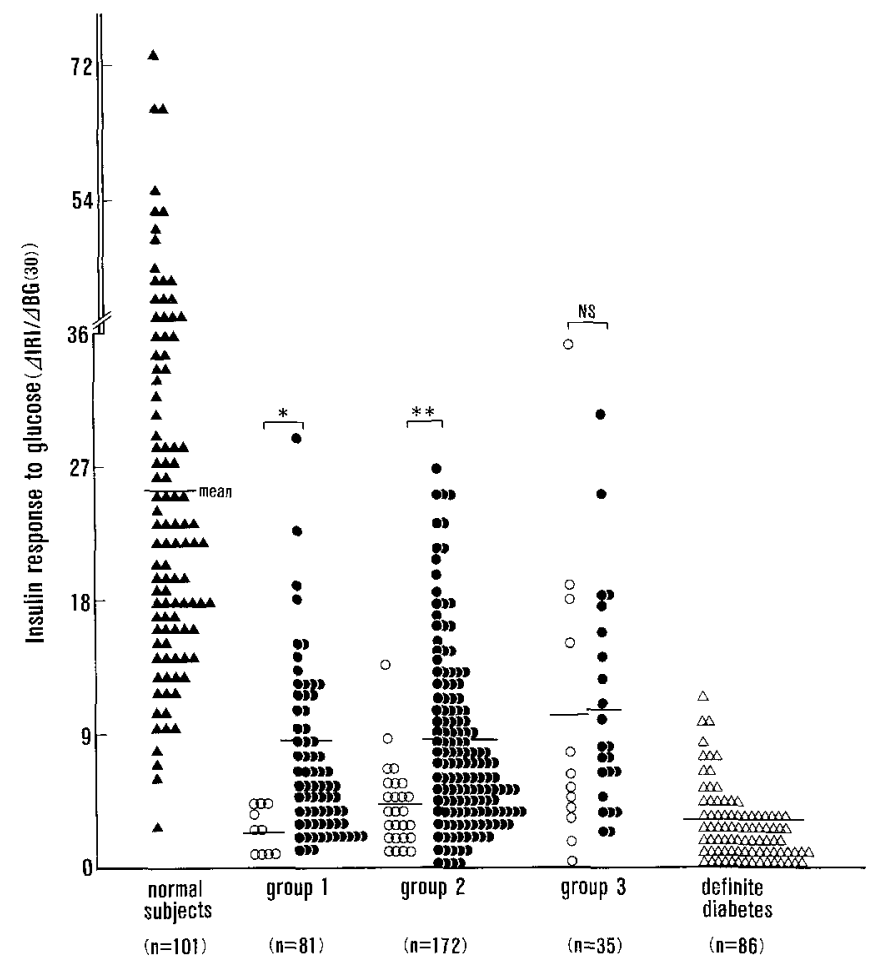

Fig. 3. Insulin response to glucose $(\Delta \mathrm{IRI} / \Delta \mathrm{BG}(30))$ in subjects with impaired glucose tolerance $(O$; those worsening to diabetes and $\boldsymbol{O}$; those not worsening), in normal subjects ( $\mathbf{\Delta}$ ) and in definite diabetes $(\triangle)$. Groups 1-3 denote subjects with impaired glucose tolerance with maximal body weight index $(<110 \%, 110-140 \%$ and $>140 \%$, respectively). NS $=$ not significant. $* p<0.05 ; * * p<0.01$

\section{Discussion}

The present study indicates by multivariate analysis that high levels of both fasting and 2-h blood glucose, obesity and diminished insulin response were all significant independent risk factors for the development of diabetes.

Results of several follow-up studies are in agreement that the initial level of blood glucose is a powerful index for predicting 'worsening to diabetes' [1-7]. Keen et al. showed recently in the Bedford 10-year prospective study of 241 people with borderline diabetes, where $36(15 \%)$ worsened to diabetes, that the major predictor for worsening to diabetes was the level of blood glucose [2]. O'Sullivan et al. demonstrated that an initial postprandial blood glucose level $\geqslant 140 \mathrm{mg} / 100 \mathrm{ml}$ proved valuable in defining a high risk group for diabetes in a 17-year follow-up study in Oxford, Massachusetts, USA [3]. In keeping up with these observations, our study confirmed again the importance of the initial level of blood glucose in predicting the subsequent development of diabetes.

In contrast with the predicting power of blood glucose level, that of obesity or low insulin response has remained controversial. Obesity is known to be the most common associated finding in Type 2 diabetes, but its predictive value for the development of diabetes has not been fully clarified. Keen et al. showed in the Bedford 10 -year study that a large body mass index did not predict a worsening to diabetes during the first 5 years, although it was an independent and significant predictor of worsening during the second 5 years [2]. Hamman et al., in a 10-year follow-up study of Pima Indians, demonstrated that next to 2 -h plasma glucose, obesity was the most significant independent predictor for decompensation of glucose tolerance [6]. Our data showed that previous maximal obesity could be regarded as a significant independent risk factor for worsening to diabetes by multivariate analysis and its influence was noticeable particularly in subjects with severe glucose intolerance. Obesity at the first visit had less predicting power for the development of diabetes than previous maximal obesity. This may be due partly to the loss of body weight by metabolic derangement at the time of the first visit even when they were obese in the past. In fact, the prevalence of obesity (body weight index $\geqslant 130 \%$ ) was $10 \%$ at the first visit, while it was $25 \%$ if the record of previous maximal body weight was included. The present data might support the idea of a 'delayed diabetogenic effect' of obesity described by Keen et al. [2].

It has been established that insulin response to glucose is decreased in definite diabetes [15-17], but the predictive value of a low insulin response for the development of diabetes remains controversial [19, 21-29]. A critical, yet still unresolved issue concerns whether those who progress to overt diabetes with fasting hyperglycaemia respond to glucose tolerance testing primarily with hypoinsulinaemia $[19,25,26]$ or hyperinsulinaemia $[22,30]$. Cerasi and Luft demonstrated that in a follow-up of non-diabetic subjects, those with low insulin response did indeed run a greater risk of developing diabetes than those with a normal insulin output [25]. Fajans et al. showed in a follow-up study of families of maturity-onset-type diabetes of the young and young non-obese mildly glucose intolerant patients that progression to insulin-requiring diabetes occurred only in individuals who had insulin responses which were delayed or low, or lower than the mean response of the control subjects [26]. The present report is the first to show that a low insulin response may be regarded as a significant independent risk factor for the development of diabetes in subjects with impaired glucose tolerance, even when one takes other risk factors into account. Thus, the idea that a diminished insulin response incurs a higher risk for the development of diabetes [19, 25, 26] was supported.

Finally, the present study of a large group of Japanese Type 2 diabetic subjects strongly suggests that low insulin secretion forms an essential basis and obesity plays a precipitating role among low-insulin responders for the development of diabetes. At the same time, it should not be disregarded that a certain number of severely obese subjects with apparently normal or high insulin secretion did develop diabetes, though they are a minority of diabetic subjects in Japan. It remains to be 
resolved whether these two groups defined by their insulin response are truly distinct or if they belong to two extreme ends of a single spectrum.

Acknowledgements. We wish to thank Mrs. K. Yanagi and Miss K. Kimura for their secretarial assistance in the preparation of the manuscript.

\section{References}

1. Jarrett RJ, Keen H, Fuller JH, McCartney M (1979) Worsening to diabetes in men with impaired glucose tolerance ('borderline diabetes'). Diabetologia 16: $25-30$

2. Keen H, Jarreet RJ, McCartney M (1982) The ten-year follow-up of the Bedford Survey (1962-1972): glucose tolerance and diabetes. Diabetologia 22: 73-78

3. O'Sullivan JB, Mahan CM (1965) Blood sugar levels, glycosuria, and body weight related to development of diabetes mellitus. $\mathbf{J}$ Am Med Assoc 194: 117-122

4. O'Sullivan JB, Mahan CM (1968) Prospective study of 352 young patients with chemical diabetes. N Engl J Med 278: 1038-1041

5. Fitzgerald MG, Malins JM (1976) Ten-year follow-up report of the Birmingham Diabetes Survey of 1962. Br Med J II: 35-37

6. Hamman RF, Bennet PH, Miller M (1978) Incidence of diabetes among the Pima Indians. Adv Metab Disorders 9:49-62

7. Sasaki A, Suzuki T, Horiuchi N (1982) Development of diabetes in Japanese subjects with impaired glucose tolerance: a seven year follow-up study. Diabetologia 22: 154-157

8. Kosaka K, Akanuma Y, Hagura R, Kuzuya N (1981) A prospective study of the development of non-insulin-dependent diabetes mellitus. In: Melish JS, Hanna J, Baba S (eds) Proceedings of the Third Symposium on Diabetes Mellitus in Asia and Oceania. Excerpta Medica, Amsterdam, pp 171-178

9. WHO Expert Committee on Diabetes Mellitus (1980) Second Report. Technical Report Series 646, WHO, Geneva

10. Kosaka K et al. (1982) Report of the Committee on the Diagnosis of Diabetes Mellitus. J Jap Diab Soc 25: 859-866

11. Kanazawa Y, Kuzuya T, Ide T, Kosaka K (1966) Plasma insulin response to glucose in femoral, hepatic and pancreatic veins in dogs. Am J Physiol 211: 442-48

12. Hagura R (1981) Oral glucose tolerance test and insulin secretory capacity - comparative study of $50 \mathrm{~g}, 75 \mathrm{~g}$ and $100 \mathrm{~g}$ glucose loads. Sogorinsho 30: 1503-1508

13. Katsura E (1965) Diet therapy in hormonal disturbances. In: Iwatsuru R (ed) Theory and practice of diet therapy, 4th Ed. Nanzando, Tokyo, pp 483

14. Seltzer HS, Allen EW, Herron AL, Brennan MT (1967) Insulin secretion in response to glycemic stimulus; Relation of delayed initial release to carbohydrate intolerance in mild diabetes mellitus. J Clin Invest 46:323-335
15. Cerasi E, Efendic S, Luft R (1973) Dose-response relation between plasma-insulin and blood-glucose levels during oral glucose loads in prediabetic and diabetic subjects. Lancet 1:794-797

16. Brunzell JD, Robertson RP, Lerner RL, Hazzard WR, Ensinck JW, Bierman EL, Porte D (1976) Relationship between fasting plasma glucose levels and insulin secretion during intravenous glucose tolerance test. J Clin Endocrinol Metab 42: 222-229

17. Kosaka K, Hagura R, Kuzuya T, Kuzuya N (1974) Insulin secretory response of diabetics during the period of improvement of glucose tolerance to normal range. Diabetologia 10:775-782

18. Seino Y, Ikeda M, Yawata M, Imura H (1975) The insulinogenic index in secondary diabetes. Horm Metab Res 7: 107-115

19. Kosaka K, Hagura R, Kuzuya T (1977) Insulin response in equivocal and definite diabetes with special reference to subjects who had mild glucose tolerance but later developed definite diabetes. Diabetes 26: 944-952

20. Cox DR (1972) Regression models and life tables. JR Stat Soc [B] 34: $187-220$

21. Pyke DA, Cassar J, Todd J, Taylor KW (1970) Glucose tolerance and serum insulin in identical twins of diabetes. Br Med $\mathrm{J} 4$ : 649-651

22. Jackson WPU, van Mieghem W, Keller P (1972) Insulin excess as the initial lesion in diabetes. Lancet 1: 1040-1044

23. Savage PJ, Bennett PH, Gorden P, Miller M (1975) Insulin response to oral carbohydrate in true prediabetics and matched controls. Lancet 1: 300-302

24. Barnett AH, Spiliopoulos AJ, Pyke DA, Stubbs WA, Burrin J, Alberti KGMM (1981) Metabolic studies in unaffected co-twins of non-insulin-dependent diabetics. Br Med J 282: 1656-1658

25. Luft R, Efendic S (1978) On the pathogenesis of maturity-onset diabetes mellitus. Acta Diabet Lat 15:1-15

26. Fajans SS, Cloutier MC, Growther RL (1978) Clinical and etiologic heterogeneity of idiopathic diabetes mellitus. Diabetes 27 : $1112-1125$

27. Kosaka K, Akanuma Y (1980) Heterogeneity of plasma immunoreactive insulin responses in patients with impaired glucose tolerance. Diabetologia 18: $347-348$

28. Keen H (1980) Heterogeneity of plasma immunoreactive insulin responses in patients with impaired glucose tolerance and diabetes. Diabetologia 19:165 (Letter)

29. Fajans SS (1980) Heterogeneity of plasma immunoreactive insulin responses in patients with impaired glucose tolerance and diabetes. Diabetologia 19: 250 (Letter)

30. DeFronzo RA, Ferrannini E, Koivisto V (1983) New concepts in the pathogenesis and treatment of noninsulin-dependent diabetes mellitus. Am J Med 74 (Suppl 1): 52-81

Received: 4 August 1982

and in revised form: 20 October 1983

Dr. Y.Akanuma

The Third Department of Internal Medicine

Faculty of Medicine, University of Tokyo

Hongo, Bunkyo-ku

Tokyo, Japan 